\title{
SIN EL CONSUELO DE \\ UN CAOS: NOTAS SOBRE \\ LO ANTIPOÉTICO
}

\section{WITHOUT THE CONSOLATION OF CHAOS: \\ NOTES ON THE ANTIPOETIC}

\section{SARA REINOSO*}

\section{RESUMEN}

Este artículo discute acerca del lugar donde se manifiesta la antipoesía. No es en el poema ni en el poeta. Luego de caracterizar al antipoeta, plantea que lo central es la creación de un personaje antipoético, y con ello nace un nuevo tipo de lector en Chile.

Palabras clave: Nicanor Parra, antipoesía, antipoeta, personaje antipoético, lector.

\section{ABSTRACT}

This article discusses the place where antipoetry comes from. It is not from the poet nor from the poem. After characterizing the antipoet, I argue that the fundamental aspect is the creation of an antipoetic character, and with this, a new type of reader is born in Chile.

Key words: Nicanor Parra, antipoetry, antipoet, antipoetic character, reader.

Recibido: 22.08.14. Aceptado: 07.10.14.

e produjo un momento en que a la poesía chilena se le debía ingresar a través de la creatividad de la poesía de Parra. En esa creatividad se encuentra uno de los mejores puntos de partida para dar con la

* Doctor en Literatura Chilena y Latinoamericana (Universidad de Chile). Profesora y coordinadora académica de ECAS (Escuela de Contadores Auditores de Santiago). Santiago, Chile. Correo: sreinoso@ecas.cl 
poesía chilena. Al mismo tiempo, la poesía de Parra comenzaba y finalizaba en la poesía chilena y la poesía chilena comenzó a mirarse desde ahí. Uno de los más serios y minuciosos estudios a propósito del fenómeno poético proviene de la antipoesía: la poesía no está en el poema y mucho menos en el poeta.

La poesía no puede emerger de la dimensión privada que es el poeta, de la dimensión privada que es el poema. Pareciera emerger de un estado interesante, producto de una relación entre una nueva subjetividad y algo, una otra cosa. Desde cierto punto de vista Nicanor Parra da el paso hacia atrás en esa línea de lo privado o privativo y crea la tradición de la negación de lo privado, negación que se inicia en algunos de los poetas anglos que lo anteceden y que lo fascinan.

La negación de lo privado, es decir, ese rompimiento con el yo encuentra su mejor sentido en la creación del personaje antipoético. El personaje antipoético crea un territorio que es equivalente a todo lo que no es el yo: unidad, pensamiento o lenguaje. Es el otro lado de la poesía. Habla desde el otro lado del poema. Por esa razón es un profundo desinteresado. Lo mejor de la narrativa puesta a circular al interior de la poesía está en la creación de ese personaje antipoético. Y desde cierto punto de vista, el personaje antipoético puede considerarse como un momento importante, como una especie de hallazgo, para la gran tradición de la literatura dramática.

Hay una tradición dramática que Parra pone a circular al interior de la poesía. Impulsado por esa tradición, particularmente en la línea del falso tonto, el personaje antipoético es el profundo escéptico. Sin duda es uno de los personajes más importantes de la literatura chilena e hispanoamericano. Pertenece al conjunto de esos personajes en virtud de los cuales se puede acceder a todo lo que no es privado en la literatura. Son tecnologías de la imaginación. El personaje antipoético viene a dar cuenta de la nueva naturaleza de la poesía.

Se ha escrito críticamente sobre el antipoeta aunque no lo suficiente sobre qué es la antipoesía, sobre toda esa compleja dimensión no privada del poeta. Se han dicho cosas muy inquietantes sobre la antipoesía, pero por la naturaleza de lo antipoético nos hemos quedado sistemáticamente atrás, de manera insistente en el pasado. Creo que la antipoesía nos dejó atrás. De algún modo está hecha para ello. Es una crítica extraña la que se ha llevado a cabo ante una materia si se quiere virtualmente actual, donde su condición más radical es su contemporaneidad constante. Su presentismo. Cada poema funciona como una maquinaria del afuera; con señas y signos 
de una inteligencia que no nos pertenece del todo. Desde cierto punto de vista la antipoesía va más adelante que la crítica todavía.

La sintaxis más bien repetitiva sobre el centramiento en la figura del antipoeta ha sido ésta: agresivo ambivalente, antihéroe alborozado, burlón bordeano, carnavalesco criticón, disociador, desmitificador, defensor del habla, des-estructurador y deconstructor, desacralizador, desjerarquizador, des-sublimador degradante, declamador, especie de Sade explosivo, enérgico y energúmeno, fíjado en el lector, fiestero, francotirador y grotesco, humorista de calibre grueso, hombre del montón e ingenioso inteligente, irónico iconoclasta, luciferino lúdico y lúbrico, medieval quebrantahuesos, revolucionario regenerador, salvador sarcástico, sofisticado taoísta subversivo, etc.

Todo lo anterior ha sido importante para formalizar la relevancia de Parra al interior de la geografía literaria de la poesía chilena, pero no formaliza la relación dramática que el personaje antipoético tiene con su teatralización, por ejemplo. La sintaxis mencionada no da con las edades del personaje antipoético. $\mathrm{Al}$ interior de la antipoesía el personaje se manifiesta también a través de edades. De bufón a anciano llorón, de joven juez a mártir ridículo acosado por la poesía. El personaje antipoético es acosado y asediado por la poesía.

Las tragedias enmarcadas al interior del texto antipoético (convocadas por la relación entre el personaje y su delirio, en todo lo que es el no dominio de sí mismo) constituyen accesos a lo que no es privado en el discurso de Parra. La sintaxis no se detiene de manera certera en lo que es, por ejemplo, el objeto central de cada poema; en el objeto trampa de cada poema. En el objeto como mediación del abismo, como enigma, como campo teórico de formación de la dimensión antipoética: los objetos como antimateria, la cualidad ambivalente de los objetos en los que se encuentra producto y productor.

Allí se encuentra una óptica sobre los procesos creativos (Parra, 2006: 57: "la verdad, como la belleza no se crea ni se pierde/ y la poesía reside en las cosas o es simplemente un/ espejismo del espíritu"). No hay discurso de lo privado en la poesía de Parra, ni siquiera el delirio está restringido al delirante dramático. Ese delirio pertenece a la dimensión del afuera porque se convierte también en un objeto. El lugar del yo es siempre un vacío, hay mecánicas para ocultar el yo. Nunca está seguro de nada, sólo hace preguntas o cuando afirma niega al mismo tiempo. Sólo habla de sí mismo cuando está muerto (Parra, 2006: 128: "Lo que el difunto dijo de sí mismo"). 
La acción en la poesía es un logro de la antipoesía. La acción radica, el trabajo radica en capturar la contradicción. La acción que no tiene sentido ni dirección se dirige hacia el vacío. Un trabajo antipoético fue el de generar vacíos. Es el trabajo de la metafísica al revés. Degastar la propagación del espacio. El problema de "El Aleph", de Borges, al revés (Borges, 1974). El sujeto allí es reducido, simplificado, es accidental. Es la desesperación del logos contra el logos, los ecos anteriores a las voces que los enuncian. Los poetas chilenos advirtieron ese territorio pasional de rechazos y atracciones creado por Nicanor. Pareciera ser que los poetas lo sienten o lo resienten. Antes sólo había poesía, no un territorio de esa naturaleza.

Los poetas chilenos fueron resistentes ante la antipoesía y todos aspiraban a ser antipoetas. Ya no es el tiempo para los antipoetas, pero me atrevo a decir que es el tiempo de la antipoesía. Y en ese terreno no podría ser de otra manera. La naturaleza antipoética reclama las preguntas en las que viaja. Las preguntas sobre el territorio que no son las preguntas por los límites de lo poético. Intentar resolver el problema del hueco vacío que es la poesía es, por ejemplo, no abandonar el territorio antipoético.

Parra configuró un sistema en que el cual el lector estaba siempre al borde de preguntas radicales, urgentes e inexistentes. Las preguntas que provocan el largo viaje del lector al presente. Preguntas que no pueden formularse como tales, pero que tienen más fuerza que una formulación. Esas preguntas no formuladas crearon a un lector. Con la antipoesía nace un lector en Chile; el de las preguntas no realizadas, si se quiere. Con acceso a un saber, sin embargo. Creó a un lector que nunca quiso ser un lector de antipoesía, pero que de pronto lo es. Debe acostumbrarse al universo denso de la contradicción. Nicanor escribió precisamente aquello que el lector en rigor no necesitaba.

El territorio antipoético nunca ha sido el de lo necesario, sí el de una nueva dimensión de lo útil. No hizo una poesía según las necesidades de un lector ni con las necesidades del poeta. Menos una poesía con las necesidades del poeta. Poeta y lector, en un sentido estricto, no existen en la antipoesía. En la poesía de Parra hay mecanismos para producir vacíos. Inventó un territorio en que el lector no se encontraba ni con la lengua, ni con un saber popular, ni con lo cotidiano. Uno en donde el poeta no se encontraba con la poesía. Es una poesía impersonal y material e irreflexiva en un sentido muy profundo. Parra configuró encuentros reales, innecesarios y urgentes. Encuentros con el afuera, con una nueva gravitación. Ese afuera sigue siendo una campana de vidrio. 


\section{REFERENCIAS}

Borges, J. L. (1974). Obras completas. $1^{\text {a }}$ ed., 617-628, Buenos Aires: Emecé.

Parra, N. (2006). Obras completas I. $1^{\text {a }}$ ed., 1068. Barcelona: Galaxia GutenbergClub de Lectores. 